\title{
KH. ABDUL WAHID HASYIM PEMBARU PESANTREN Dari Reformasi Kurikulum, Pengajaran hingga Pendidikan Islam Progresif
}

\author{
Umiarso \\ Dosen FAI Universitas Muhammadiyah Malang, Jawa Timur, Indonesia \\ umiarso@umm.ac.id \\ Asnawan \\ Dosen INAIFAS Kencong Jember, Jawa Timur Indonesia \\ asnawanwan@gmail.com
}

\begin{abstract}
KH. Abdul Wahid Hasyim known as the father of the nation and the young ulama was able to pioneer the reform of the Islamic education system, especially in pesantren. To reform those pesantren, the breakthroughs done by $A W H$ were broken down on three major agendas. They are updating the teaching methodology, improving the quality of the human resources or students, and developing institution and curriculum. Therefore, this article attempts to analyze the progressive efforts of AWH that "broke down" the backwardness and reluctance of the pesantren. In this study, the researcher used qualitative approach as the type of literature study and content analysis as the data analysis. This article discovers the style of educational innovation in pesantren, ie: getting familiar with modern methodologies; increasingly oriented towards functional education or open into the development; diversification of programs, pesantren activities are increasingly open, its dependence on kiai is not absolute, and at the same time it can equip students with a variety of knowledge outside of religious learning and skills needed by the world of work; and it can function as a community development center.
\end{abstract}

Keyword: Educational Reform, Teaching Methodology, and Curriculum Reform. 


\begin{abstract}
Abstrak
KH. Abdul Wahid Hasyim yang dikenal sebagai bapak bangsa dan ulama muda mampu mempelopori pembaruan sistem pendidikan Islam terutama di lembaga pesantren. Untuk mereformasi pesantren tersebut, terobosan yang dilakukan $\mathrm{AWH}$ terurai pada tiga agenda besar, yaitu: pembaruan pada bidang metodologi pengajaran, peningkatan kualitas SDM para santri, serta pengembangan institusi dan kurikulum. Oleh karenanya, artikel ini mencoba menganalisis upaya progresif $\mathrm{AWH}$ yang "mendobrak" keterbelakangan dan keterbelengguan pesantren. Dalam penelitian ini, peneliti menggunakan pendekatan kualitatif dengan jenis penelitian studi pustaka dan analisa data menggunakan content analysis. Artikel ini menemukan corak inovasi pendidikan dalam pesantren, yaitu: mulai akrab dengan metodologi modern; semakin berorientasi pada pendidikan yang fungsional atau terbuka atas perkembangan yang ada; diversifikasi program dan kegiatan makin terbuka dan ketergantungannya dengan kiai tidak absolut, dapat membekali santri dengan berbagai pengetahuan di luar pelajaran agama maupun keterampilan yang diperlukan dunia kerja; dan dapat berfungsi sebagai pusat pengembangan masyarakat.
\end{abstract}

Kata Kunci: Reformasi Pendidikan, Metodologi Pengajaran, dan Reformasi kurikulum.

\title{
A. Pendahuluan
}

Sebagai seseorang yang dikenal sebagai salah satu pendiri bangsa, KH. Abdul Wahid Hasyim, selanjutnya ditulis AWH, juga dikenal sebagai salah seorang pembaru pesantren. Hal ini bisa dimaklumi, sebab pemikiran-pemikiran dirinya tidak lepas dari gerak progresifitas inovasi sistem pendidikan pesantren. Sebagaimana riset yang dikembangkan oleh Moh. Ismail (2016, 315-36) yang menyimpulkan bahwa AWH mampu menghadirkan konsep pendidikan Islam yang demokratis; riset Nindia Puspitasari (2017, 105-23) yang menyimpulkan tentang ada 12 nilai yang ditekankan $\mathrm{AWH}$ dan sejalan dengan tujuan pendidikan karaktek yang multikulturalis dan religius; atau riset As'ad (2012) dengan menyimpulkan bahwa AWH mampu meramu dimensi kemodernan dan tradisi pendidikan Islam dengan landasan ke Islaman, sehingga sistem pendidikan Islam memiliki identitasnya sendiri. Bentuk dan corak pemikiran yang progresif tersebut merupakan indikator 
dari sosok visioner AWH. Menariknya, semua pemikiran inovasi tersebut dirancang dan diimplementasikan dalam dunia pesantren sebagai medium atau wadah untuk menyebarkannya-sebagaimana pendahulunya (Solikhin 2016, 331-64).

Dalam pandangan AWH sendiri, pesantren merupakan lembaga pendidikan yang membentuk intelektualitas dirinya. Bahkan ia sejak kecil dididik di kalangan santri yang teguh menjalankan nilai-nilai Islam, sehingga denyut nadi kehidupan dirinya tidak lepas dari pesantren. Wajar apabila muncul anggapan bahwa ia mampu melahirkan pemikiran-pemikiran cerdas yang inovatif untuk memajukan pesantren disebabkan karena ia dibesarkan oleh lingkungan pesantren. Jika anggapan ini benar adanya, pemikiran pendidikan Islam yang dihasilkan tidak lepas dari spirit esensial kelembagaan pesantren. Karenanya, pemikiran AWH senantiasa menukik ke pokok persoalan pesantren yang sedang dihadapi dan memberikan solusinya pada saat ini dan di masa yang akan datang. Wajar apabila pemikiran-pemikirannya terkesan progresif dan liberal pada zamannya, salah satunya ketika ia mendidik santri ia sangat mengedepankan pola dialektis-kritis daripada indoktrinasi (Atjeh 1957, vii). Bahkan ia memasukan materi pelajaran umum ke dalam sistem pendidikan pesantren yang pada saat itu sangat tabu ada dalam kurikulum pesantren.

Hal tersebut merupakan bentuk penyelarasan sistem pendidikan pesantren dengan alur perkembangan zaman yang terus bergulir-seirama dengan modernitas (ilmu pengetahuan dan teknologi). Tanpa meninggalkan nilai-nilai normatif pesantren yang telah tertanam kuat, AWH melakukan terobosan yang fundamental sesuai laju semangat zaman. Sebagaimana pada tahun 1934, ia melakukan inovasi radikal yaitu dengan mendirikan madrasah Nizhamiyah dengan konstruksi kurikulum $70 \%$ materi pengetahuan umum. Sejak saat itulah, pesantren mulai akrab dengan kitab-kitab modern yang lahir dari rahim pemikiran dialektis-kritis ulama-ulama khalaf. Di satu sisi, buku-buku sekuler dari belahan dunia Barat seperti dari bangsa Eropa atau juga Amerika terus menerus mengisi rak-rak perpustakaan pesantren. Bahkan pada tahun 1950, ia terus berinovasi yaitu dengan melakukan reorganisasi terhadap madrasah yang ada di pesantren Tebuirengyang akhirnya menjadi referensi sistem pendidikan nasional. 
Bahkan dalam salah satu riset yang dilakukan oleh Maragustam (2016, 325-46) dikatakan bahwa AHW dalam filsafat pendidikan Islam terutama terhadap sistem pendidikan pesantren memiliki posisi yang positif-aktif dan religius-rasional pragmatis. Dikatakan demikian, dikarenakan ia mampu melakukan rekonstruksi terhadap pesantren seperti meletakan dasar pesantren pada dua pancangan (yaitu dasar ayat-ayat qauliyah dan kauniyah); atau rekonstruksi kurikulum pesantren diarahkan pada konsep kesimbangan antara tradisi ilmu ke Islaman dan Barat (sekuler). Artinya, pemikiran-pemikiran AWH memiliki relasi kuat terhadap bangunan kependidikan Islam terlebih lagi terkait dengan sistem pendidikan pesantren. Lazim apabila AWH ditempatkan sebagai tokoh garda depan dalam mengurai arus transformasi sistem kependidikan di pesantren seperti halnya Achmad Zaini (1998) atau bahkan sebagai sosok nasionalis bangsa sebagaimana yang dikatakan Greg Barton (2002, 45).

Semua pemikiran AWH tersebut pada hakikatnya akan bermuara pada peningkatan kualitas pendidikan Islam terutama di pesantren. Oleh sebab itu, ada beberapa peneliti seperti Moh. Hadi Santoso \& Sumarno (2015, 335-43) yang secara kritis mengurai pemikiran-pemikiran AWH tentang reformasi pendidikan pesantren tersebut; atau juga Achmad Zainal Arifin (2013) mengkaji modernisasi yang terjadi pesantren terjadi akibat meleburnya ilmuilmu sekuler (rasionalitas) sebagaimana yang dilakukan AWH. $\mathrm{Hal}$ ini menandakan bahwa pemikiran-pemikiran $\mathrm{AWH}$ tersebut memiliki sisi positif untuk terus didialogkan dengan realitas kekinian untuk menyosong sistem pendidikan yang lebih baik. Artinya, pada saat ini pemikiran-pemikiran AWH bisa dijadikan sebagai landasan konstruksi pendidikan Islam progresif di tengah perkembangan ilmu pengetahuan dan teknologi, yang lazim dikatakan sebagai era disrupsi (era milenial).

Penulis pada konteks artikel ini mencoba untuk mengurai pemikiran-pemikiran AWH tentang laju gerak reformasi pendidikan pesantren yang meliputi metode, sumber daya manusia santri, kurikulum dan lain sebagainya. Artinya, riset ini secara kritis menganalisis upaya progresif yang "mendobrak" keterbelakangan dan keterbelengguan sistem pendidikan pesantren untuk terus melaju 
beriringan dengan modernitas. Oleh sebab itu, penulis menggunakan pendekatan kualitatif untuk memahami pemikiran-pemikiran kritis AWH tersebut. Lazim apabila artikel ini masuk dalam jenis studi pustaka, sehingga teknik pengumpulan datanya lebih banyak menggunakan dokumentasi; dan analisa data yang digunakan adalah content analysis. Dari kerangka inilah, penulis mencoba untuk membangun konsep pendidikan Islam progresif sebagai alternatif sistem pendidikan di masa depan.

\section{B. Pembahasan}

\section{Riwayat Hidup AWH}

AWH adalah putra kelima pasangan K.H. M. Hasyim Asy'ari dengan Nyai Nafiqah, yang merupakan puteri Kiai Ilyas dari Madiun (Abdullah 1996, 274). Ia adalah lelaki pertama dari 10 bersaudara yang lahir pada Jumat, 1 Juni 1914. Dari nasabnya, AWH merupakan keturunan Joko Tingkir, tokoh yang kemudian lebih dikenal dengan Sultan Sutawijaya yang berasal dari kerajaan Islam Demak (Atjeh 1957).

Sejak kecil, AWH diperkenalkan dengan pengetahuan Islam dan dibebaskan untuk mempelajari pengetahuan umum. Tidak soal baginya bagaimana mendapatkan buku bahan bacaan walaupun kondisi ekonomi tergolong mampu. AWH kecil memiliki otak yang cerdas, ia sudah pandai membaca Al-Qur'an dan sudah khatam ketika berusia 7 tahun. Selain itu, dalam usia demikian belia, AWH sudah mengaji kitab Fathul Qarib (Syarah Kitab Matnal-Taqrib), dan kitab Minhaj al-Qawim, serta mulai gemar mempelajari sastra Arab, terutama syai'r-syair' Arab seperti dalam kitab Diwan al-Syu'ara (kumpulan penyair dan syair-sya'irnya) (Suprapto 2009, 152). Pada usia 12 tahun, AWH mampu menamatkan Madrasah Tsanawiyah, dan mulai mengajar adik-adiknya, serta teman-teman sebayanya (Ma'shum 1994, 313).

Walaupun sebagai anak tokoh terkemuka, AWH tidak pernah mengenyam pendidikan di bangku sekolah Pemerintah Hindia Belanda. Dia lebih banyak belajar secara mandiri. Karena dianggap sudah memiliki basis pendidikan Islam yang baik, maka pada usia 13 tahun dia dikirim ke Pondok Siwalanpanji Sidoarjo. Ternyata di sana dia hanya bertahan sebulan. Kemudian ia mondok di Pondok 
Pesantren Lirboyo Kediri. Ia hanya sebentar di sini (Ma'shum 1994). Setelah mondok, yang seringkali hanya sebentar itu, ia kembali ke rumahnya dan belajar huruf latin, serta mulai mempelajari Bahasa Belanda dan Inggris, tentu setelah ia mahir berbahasa Arab. Karena memiliki minat baca yang tinggi dan semangat menuntut ilmu, tak heran jika di usia yang masih muda itu ia berlangganan majalah-majalah yang berbahasa Melayu maupun berbahasa asing (Atjeh 1957).

Menginjak usia 18 tahun, pada 1932, ia berangkat ke Makkah, di samping menuntut ilmu juga menunaikan ibadah haji. Sebab di saat itu, Mekkah dianggap sebagai pusat untuk mempelajari Islam. Ia ke Mekkah ditemani sepupunya, Muhammad Ilyas, yang nantinya juga menjadi Menteri Agama RI.

Bagi kalangan santri di Jawa dan pulau-pulau lain, nama Hasyim Asy'ari sangat dikenal luas dan dihormati. Bukan saja karena ia adalah pendiri NU (organisasi Islam terbesar di Indonesia), tetapi disebabkan ia juga merupakan kiai pendiri sekaligus pengasuh pondok pesantren Tebuireng, Jombang, Jawa Timur. Pengaruh KH. Hasyim Asy'ari makin meluas hal ini ditandai dengan begitu banyak santrinya, yang kemudian mendirikan pesantren setelah belajar dengan beliau (Azra dan Umam 1998, 98). AWH yang hidup dalam lingkungan pesantren yang relegius membentuk kepribadiannya dalam cara bergaul, berorganisasi, mendidik menjadi seorang pemimpin dan bahkan menjadi seorang negarawan. Kepribadian AWH adalah profil yang memiliki kepribadian lintas batas, artinya tidak sekedar di bentuk dari pergesekan, dialektikanya dengan komunitas pesantren dan NU, tapi dengan berbagai komunitas seperti dengan organisasi pergerakan Islam, partai politik dan juga birokrasi pemerintahan ketika dirinya menjabat sebagai Menteri Agama.

Telah dinyatakan pada kalimat sebelumnya bahwa AWH merupakan seorang yang cerdas, dan kecerdasan tersebut semakin ia lengkapi dengan sering membaca dan menulis. Dua aktivitas ini (membaca dan menulis) tidak lepas dari kesehariannya dan merupakan kegemaran $\mathrm{AWH}$, sehingga lazim jika ia dikenal sebagai intelektual muda kala itu, dengan gagasan-gagasannya yang cemerlang. Dalam kasus terkait kegemarannya membaca inilah, Saifuddin Zuhri berkomentar bahwa AWH membaca buku apa saja 
tanpa memilih judul. Mengambil secara berurutan, buku-buku yang tersusun di rak hingga seluruh buku habis dibacanya. Karenanya, tidaklah mengherankan jika AWH mengetahui pengetahuan umum di berbagai bidang seperti sejarah, pengetahuan alam, filsafat, politik, ekonomi, seni budaya, dan lain-lainnya.

Menariknya pula, kegemaran membaca yang tertanam dalam diri $\mathrm{AWH}$, kemudian ia implementasikan dengan cara menulis. Karenanya, AWH disebut-sebut sebagai penulis yang subur, banyak artikel-artikel yang telah ia tulis dalam berbagai bidang seperti keagamaan, politik, dan lain sebagainya. Meskipun karya-karya tersebut tidak dipublikasikan secara tersendiri oleh AWH menjadi sebuah buku, akan tetapi ia lebih memilih untuk mempublikasikannya ke dalam berbagai majalah dan koran. Karya-karyanya dapat diklasifikasikan atas 4 bagian utama, yaitu: pendidikan, politik, kementerian agama di Indonesia dan agama (Zaini 2011b, 30). Bahkan ada pula karangan pendek yang ia muat di berbagai surat kabar atau majalah (Latifah dan Alfian 2005, 516). Berbagai tulisan AWH dapat diidentifikasi cukup baik oleh Aboebakar Atjeh dalam Sejarah Hidup KH.A. Wahid Hasyim dan Karangan Tersiar, serta oleh Buntaran Sanusi dalam KH. A. Wahid Hasyim: Mengapa Memilih NU (Konsepsi tentang Agama, Pendidikan dan Politik).

AWH meninggal dalam kecelakaan mobil tatkala berencana menghadiri rapat NU di Sumedang pada hari Sabtu tangga 18 April 1953 (Sutjiatiningsih 1984, 64). Indonesia mengalami kedukaan yang amat mendalam atas meninggalkan seorang AWH yang merupakan muslim reformis sekaligus pahlawan kemerdekaan, yang berjuang untuk mempersatukan kedaulatan Nusantara saat terjadi kolonialisme Belanda dan Jepang. Sebab AWH memiliki jasa besar terhadap pernak-pernik perjalanan sejarah bangsa Indonesia. Bahkan kemampuan kepemimpinan dan organisasi AWH sangat diakui oleh teman, kerabat atau musuh-musuhnya. Lazim apabila Muhammad Natsir, sosok besar negarawan sejati menyatakan bahwa "... sahabatku telah tiada” (Dhofier 1982, 136). Bahkan Greg Barton (Barton 1997, 40), yang merupakan seorang peneliti memberikan ungkapkanbahwa mungkin kalau saja AWH tidak meninggal saat kecelakan kendaraan pada Tahun 1953, situasi perkembangan Indonesia akan berbeda. Lazim jika ada kalangan yang melihat bahwa AWH merupakan 
seorang tradisionalis yang memiliki pemikiran-pemikiran yang progresif terhadap perkembangan pesantren, ia juga seorang yang mediator terkemuka dalam dialog antara tradisionalis dan modernis (Zaini 2011b).

\section{Pemikiran Pembaruan Pendidikan Pesantren AWH}

Sebagai seorang yang lahir, dididik, dan dibesarkan dilingkungan pesantren, wajar apabila arus pemikiran $\mathrm{AWH}$ sangat kental dengan nilai-nilai ke Islaman. Berkat kecerdasan yang luar biasa dan pergaulan yang luas, mendorong cakrawala wawasan $\mathrm{AWH}$ tidak hanya terbatas di pesantren saja. Ia tampil menjadi tokoh nasional yang ikut mewarnai sejarah kemerdekaan, dan salah satu yang membidani konstitusi di Indonesia. Untuk itulah, dalam salah satu tulisannya, ia mengajak umat Islam untuk bangkit dan keluar dari stagnasi peradaban. AWH menyerukan dua strategi perjuangan umat Islam, yaitu: Pertama, tingkatan "tenaga mobil", yaitu tenaga pemimpin-pemimpin yang berpendidikan cara Barat, namun tak punya pengaruh di basis massa; dan kedua, tingkatan tenaga massa melalui pengaruh para ulama yang punya pengaruh kuat di tingkatan massa (Sanusi, Kaloke, dan Kusnandar 1985, 122).

Gagasan pembaruan pendidikan pesantren dari AWH bisa dilacak semenjak ia pulang dari belajar di Makkah. Sejak saat itu ia mulai aktif membantu ayahnya mendidik para santri. Karena memiliki semangat perubahan yang tinggi, didukung basis epistemologi Islam dan keilmuan modern, maka yang ia lakukan adalah mengupayakan pembaruan pendidikan di pesantrennya. Dalam berbagai pemikiran dan tindakannya, AWH menekankan perlunya pesantren melakukan inovasi agar up-date dan bergerak dinamis dengan ritme gelombang perkembangan zaman. Sebagaimana diketahui, dinamika sistem pendidikan pesantren adalah pergeseran, perubahan dan perkembangannya pesantren sesuai dengan perkembangan zaman. Dan faktor yang tidak bisa dipungkiri adalah relevansi kualitas dari sistem pendidikan pesantren yang sangat bergantung pada kualitas kiai sebagai tokoh kunci. Maka dari itu, yang dilakukan oleh AWH adalah peningkatan kualitas para santri. Di antara sasaran perubahan yang ia lakukan adalah metode yang digunakan dalam proses belajar mengajar, tujuan dan harapan santri belajar di pesantren 
dan pengenalan mata pelajaran dari Barat (Zaini 2011, 36). Secara garis besar pembaruan pendidikan Islam terutama di pesantren yang dilakukan oleh AWH bisa diklasifikasikan dalam beberapa aspek, antara lain: metode pengajaran, kurikulum dan pembaruan institusi.

\section{a. Pembaruan di Bidang Metode Pengajaran}

Dalam hal pembaruan metode pengajaran dalam pendidikan Islam khusus di pesantren, AWH mengkritik dua metode pembelajaran yang telah lama diterapkan, yaitu sorogan dan bandongan. Pada sistem sorogan, seorang guru harus mengawasi, menilai, dan membimbing secara individual kemampuan seorang santri. Di sisi lain, santri juga dituntut harus "mempresentasikan" kemampuannya dalam membaca kitab kuning face to face dengan sang kiai. Sedangkan pada sistem bandongan, seorang guru akan membacakan, menerjemahkan, menerangkan, dan mengulas sebuah kitab yang dalam hal ini adalah kitab klasik (lazim disebut kitab kuning) di hadapan sekelompok santri yang mendengarkan dan menyimak penjelasan tersebut sambil memberi catatan pada kitab miliknya sendiri. AWH pada kerangka ini tidak ingin menghapus metode pengajaran tersebut, tetapi hanya mengusulkan untuk mengadopsi sistem tutorial, sebagai ganti dari metode bandongan.

Menurut AWH, metode bandongan sangat tidak efektif dalam mengembangkan inisiatif santri (Dhofier 1984). Hal ini disebabkan, di majlis ilmu dimana metode bandongan diterapkan, santri hanya datang mendengar, menulis, dan menghafal pelajaran yang diberikan; tidak ada ruang atau kesempatan bagi santri untuk mengajukan pertanyaan dan bahkan mendiskusikan pelajaran. AWH sampai pada kesimpulan awal bahwa metode bandongan menjadikan santri pasif dan cenderung tidak produktif. Selain itu, menurut $\mathrm{AWH}$, sistem bandongan menutup rapat pintu kreativitas dan inisiatif santri karena hanya berlangsung satu arah. Dialog antara kiai dan santri menjadi sesuatu yang "tabu" atau bahkan "haram" keberadaannya.

Untuk itulah ia menawarkan ide tentang pengajaran memakai metode tutorial. Metode ini tidak perlu dilakukan oleh guru/kiai secara langsung, tetapi juga bisa dilakukan oleh para santri senior selaku badal (wakil) dari guru/kiai. Dengan metode ini, para santri dibiasakan untuk terlibat dalam diskusi intensif dengan para tutornya. Selain itu, nampaknya dengan menerapkan sistem ini, AWH berharap 
dapat mengurangi hubungan patron-klien yang masih sangat kuat di antara kiai/guru dan santri. Proses memperoleh ilmu pengetahuan bagi para santri, perlu disesuaikan dengan prinsip-prinsip logika atau rasionalitas. Penggunaan logika ini ditekankan AWH dalam metode pembelajaran memakai sistem tutorial, sehingga santri memiliki ruang kreatif dan improvit dalam pembelajaran. Bahkan pada konteks ini, dialektika pemikiran merupakan sebuah hal yang ditekankan untuk menemukan dan melebarkan pemikiran. Proses pengajaran sistem tutorial ini pun sesungguhnya juga memancing nalar kritis para santri agar leluasa melakukan analisis sesuai dengan kapasitas keilmuannya.

Selain itu, AWH juga mengoreksi harapan para santri belajar di pesantren. Ia mengusulkan agar kebanyakan santri yang datang ke pesantren tidak berharap menjadi ulama'. Karenanya, mereka tidak perlu menghabiskan waktu bertahun-tahun dalam mengakumulasi ilmu agama melalui teks-teks Arab. Mereka dapat memperoleh ilmu agama dan buku-buku yang ditulis dengan huruf latin dan menghabiskan sisa waktunya untuk mempelajari berbagai ilmu pengetahuan dibarengi kemampuan menguasai keterampilan yang berguna secara langsung di tengah masyarakat dimana mereka berada. Hanya sebagian kecil saja yang memang dipersiapkan untuk menjadi ulama yang diajarkan karya klasik para ulama shaleh (as-salaf as-shaleh) (Atjeh 1957). Hanya saja dua usulan tersebut masih belum diterima oleh KH. M. Hasyim Asy'ari; karena ide-ide AWH ini masih dianggap radikal dan bertolak belakang dengan pemikiran para kiai saat itu (Atjeh 1957).

Selain ide-ide tersebut, menurut Masyhuri (2008, 19-20) ada beberapa ide inovatif lainnya yang AWH tawarkan sebagai ide alternatif, antara lain: pertama, para santri tidak perlu menghabiskan waktu sampai puluhan tahun untuk belajar bahasa Arab dan mengakumulasi pengetahuan dari para kiai berbagai pesantren; kedua, para santri dapat mempelajari agama Islam dari buku-buku yang ditulis dengan bahasa non-Arab; dan ketiga, para santri dapat memfokuskan waktunya untuk mempelajari berbagai pengetahuan dan keterampilan lainnya yang dapat digunakan untuk kepentingan dirinya sendiri dan masyarakat. Pada hakikatnya, inovasi yang ditawarkan oleh $\mathrm{AWH}$ ini merupakan jawaban atas kritik yang 
dialamatkan ke pesantren sebagai lembaga yang dianggap statis dan jumud. Pesantren berada di wilayah yang sedikit ambigu; ia tidak harus meninggalkan keemasan "masa lalu" sekaligus membuka ruang untuk mengadaptasi berbagai inovasi yang relevan dan kontekstual. Hal ini merupakan sebuah implementasi dari sebuah adagium yang berbunyi al-Muhafadhat 'ala al-Qadimal-Salihwaal-Akhdzbial-Jadid al-Aslah yang secara bebas dimaknai sebagai upaya "menjaga sesuatu yang lama (klasik) yang positif, sambil mengadopsi sesuatu yang baru yang lebih aktual dan positif".

Pengaplikasian adagium tersebut merupakan sebuah bentuk implementasi ruang dinamis pesantren. Di satu sisi, sebagai lembaga pendidikan Islam, pesantren dengan kukuh menjaga dan melestarikan warisan klasik (al-turathal-qadim) berupa khazanah keilmuan Islam zaman keemasan yang lazim disebut "kitab kuning". Sehingga dari kerangka ini, pesantren tetap menjaga kesinambungan nilai-nilai pemikiran ke Islaman yang dimuculkan oleh ulama salaf.

Melihat konstruksi tersebut, jelasnya pemikiran progresif terkait dengan reformasi sistem kependidikan pesantren yang dilakukan oleh AWH tetap mempertahankan metode bandongan dan sorogan-nilai-nilai lama (yang baik) sembari menyisipkan metode pembelajaran tutorial-nilai baru (yang lebih baik). Selain itu, dengan mengubah perspektif "tujuan santri" belajar di pondok, ia berharap dimanapun nantinya santri berada, ia bisa mengabdi di masyarakat sebagai seorang ulama' yang beretika dengan membawa kemanfaatan, bukan hanya melalui jalur keagamaan saja.

Dengan demikian, berbagai hal yang dilakukan oleh $\mathrm{AWH}$ melalui pola pembaruan metodologis maupun pembaruan perspektif para santri belajar di pondok, memiliki relevansi gagasan pembaruan pendidikan Islam sebagaimana yang pernah digagas oleh pemikir modernis kebangsaan Pakistan yaitu Fazlur Rahman. Keterkaitan tersebut terutama pada analisis tentang kebangkitan pendidikan Islam; ia menyatakan, ...membangkitkan ideologi umat Islam tentang pentingnya belajar dan mengembangkan ilmu pengetahuan. Ia juga melajutkan bahwa ...pembaruan di bidang metode pendidikan Islam yaitu dari metode mengulang-ulang dan menghafal pelajaran ke metode memahami dan menganalisis (Sutrisno 2006, 167). 


\section{b. Pembaruan di bidang Peningkatan SDM Santri}

Selain itu, AWH juga melakukan pembaruan sistem pendidikan pesantren di bidang peningkatan SDM santri. Apalagi diri AHW adalah seorang yang memiliki visi masa depan, tidak heran jika ia memilih mendirikan perpustakaan di Tebuireng. Jumlahnya \pm 1.000 koleksi buku dengan berbagai tema. AWH sendiri mempunyai keyakinan jika perpustakaan merupakan sarana untuk meningkatkan kemampuan santri di bidang intelektual maupun aktivitas di masyarakat (Atjeh 1957).

Memang jika dilihat dari aspek teoritis, perpustakaan mempunyai tiga kegiatan pokok, yaitu: pertama, mengumpulkan (to collect) semua informasi yang sesuai dengan bidang kegiatan dan misi organisasi dan masyarakat yang dilayaninya. Kedua, melestarikan, memelihara, dan merawat seluruh koleksi perpustakaan, agar tetap dalam keadaan baik, utuh, layak pakai, dan tidak lekas rusak baik karena pemakaian maupun karena usianya (to preserve). Dan ketiga, menyediakan dan menyajikan informasi untuk siap dipergunakan dan di berdayakan (to make availlable) seluruh koleksi yang dihimpun di perpustakaan untuk dipergunakan pemakainya (NS. 2003, 1). Melihat kegiatan perpustakaan tersebut bisa dikatakan bahwa AWH telah melakukan lompatan epistemologis untuk meningkatkan SDM santri. Bahkan lompatan tersebut mampu memadukan sisi keilmuan keagamaan dengan ilmu-ilmu sekuler.

Artinya, santri dikenalkan dengan berbagai ilmu pengetahuan yang diarahkan pada pembentukan wawasan keilmuan agama dan non agama. Dengan bekal keilmuan integratif ini, AWH mengharapkan santri tidak hanya menjadi sosok yang ahli ilmu agama tapi juga bisa berkiprah di ranah yang berbeda dengan pengetahuan lainnya. Dari dasar inilah, AWH sangat percaya akan kekuatan perpustakaan sebagai medium untuk membuka wawasan santri melalui koleksi referensi (buku, kitab kuning, dan lain sebagainya). Wajar apabila, AWH terus menerus melakukan pembenahan untuk meningkatkan SDM santri yang dianggap tidak harus menjadi sosok ulama'-ahli dalam bidang agama saja. Apalagi ia berkeyakinan bahwa tujuan santri berada di pesantren adalah untuk menjadi subjek yang bertaqwa dan memiliki keterampilan untuk hidup. Artinya, AWH melakukan investasi SDM pesantren dengan membekali para santri dengan wawasan dan 
pengetahuan integralistik (agama dan umum) serta keterampilan. Pada konteks ini bisa dikatakan bahwa AWH memberdayakan potensi head (rasionalitas), heart (spiritualitas), dan hand (keterampilan).

Dengan demikian, AWH sangat memperhatikan tumpuan serta tujuan utama reformasi sistem pendidikan pesantren yang berakhir pada SDM santri. Hal ini juga bisa dibaca bahwa AWH mementingkan dan meningkatkan harkat serta martabat kemanusiaan santri -baca subjek dan objek pendidikan Islam. Sebagaimana dalam salah satu riset yang dilakukan oleh Zainuddin Syarif \& Abdul Gaffar (2012) yang menemukan, di dalam pemikiran pendidikan $\mathrm{AWH}$ terdapat pendidikan multikulturalisme tauhidiq. Ini merupakan representasi upaya atau satu medium untuk melakukan metamorfosis keshalehan sosial melalui kesetaraan dan keadilan sosial dalam pembelajaran.

\section{c. Pembaruan Pendidikan di Bidang Institusi dan Kurikulum}

Gagasan pembaruan pendidikan yang monumental pada lintasan era kehidupan AWH adalah saat ia mempelopori berdirinya Madrasah Nizamiyah pada tahun 1935. Munculnya madrasah ini terinspirasi dari kegemilangan Madrasah Nizamiyah yang dibangun pemimpin Saljuk, Nizamul Mulk, pada tahun 1092. Awalnya, AWH memang memandang bahwa terbatasnya mata pelajaran yang diberikan di pesantren, membuat santri sulit bersaing dengan temannya yang belajar dengan menggunakan sistem pendidikan Barat. Kelemahan santri, menurutnya adalah kurangnya penguasaan terhadap ilmu-ilmu Barat, seperti penguasaan bahasa asing dan keterampilan hidup (Atjeh 1957). Dengan dibekali keterampilan hidup, ia berharap para santri mampu bersaing untuk memperebutkan posisi dan peranan penting di tengah masyarakat seperti lulusan lembaga pendidikan umum. Madrasah yang awal mulanya tidak disetujui oleh ayahnya ini kemudian dikelola dengan menggunakan sistem klasikal atau berjenjang, sebuah hal baru di pesantren saat itu. Aboebakar Atjeh menilai, gagasan modernisasi pesantren dengan corak klasikal ini memang merupakan gagasan orisinil AWH, sebab tidak ada kemiripan tipe madrasah yang dibangun di Indonesia, sebelum berdirinya Madrasah Nizamiyah yang digagas oleh AWH (Atjeh 1957). 
Ahmad Zaini (2011, 47) bahkan menilai bahwa gagasan modernisasi kurikulum pesantren melalui pola klasikal (berjenjang) yang digagas $\mathrm{AWH}$ juga banyak dipengaruhi oleh sekolah model Barat. Dia berargumen bahwa Moh. Ilyas sepupu AWH, yang belakangan juga menjadi Menteri Agama RI adalah lulusan HIS (Holland Indische School) adalah sosok yang memberikan pengaruh besar terhadap ide modernisasi yang dilakukan oleh AWH. Pada akhirnya, Zaini memiliki kesimpulan bahwa sistem pembaruan pendidikan yang digagas oleh AWH merupakan model yang unik, yakni model pendidikan yang cukup moderm yang menggabungkan model pendidikan pesantren dengan model yang dikembangkan di sekolah Barat.

Selain memakai pola klasikal, Madrasah Nizamiyah juga memakai kurikulum integral antara ilmu agama dan ilmu umum. AWH menolak anggapan adanya pemisahan antara ilmu agama dan ilmu umum. Karena itulah, yang pertama kali ia lakukan melalui Madrasah Nizamiyah adalah dengan memperbarui kurikulum. Institusi baru yang digagas oleh AWH menggunakan ruang kelas dengan kurikulum $70 \%$ pelajaran umum dan 30\% pelajaran agama (Zaini 2011a).

Meskipun ia tak pernah mengenyam pendidikan di sekolah Barat yang dikelola Belanda, akan tetapi dengan visi pendidikannya, AWH memperkenalkan ilmu-ilmu umum (sekuler) di Madrasah Nizamiyah, seperti aritmatika, sejarah, geografi, dan ilmu pengetahuan alam, lalu disertai dengan pelajaran bahasa Indonesia, Inggris dan Belanda. Pada dasarnya ada tiga pendekatan pembaruan pendidikan yang dilakukan pada waktu itu, yaitu pengislaman pendidikan sekuler modern, menyederhanakan silabus-silabus tradisional dan menggabungkan cabang-cabang ilmu pengetahuan lama dengan cabang-cabang ilmu pengetahuan modern. AWH memilih melakukan aspek yang ketiga. Dengan demikian terjadi keseimbangan pola pikir para santri.

Inovasi AWH dalam merombak secara evolutif kurikulum pesantren Tebuireng, melalui Madrasah Nizamiyah, sesungguhnya merupakan usaha memenuhi standarisasi lulusan bagi para santri yang cakap dan mandiri. Selain itu, hal ini merupakan bentuk aktualisasi kebijakan AWH dalam standarisasi isi dalam dunia pendidikan, sehingga terciptanya keseimbangan (tawazun) ilmu-ilmu 
naqliah dan 'aqliyah, antara keilmuan agama yang disakralkan dan keilmuan umum yang profan. Penerapan metode tutorial di samping sistem bandongan, sorogan, dan musyawarah (untuk santri senior pondok Tebuireng) merupakan terobosan penting yang membawa pengaruh besar pada pembaruan pendidikan pesantren pada tahuntahun berikutnya. Apa yang telah dilakukan oleh AWH memiliki efek jangka panjang karena pesantren Tebuireng saat itu menjadi pusat pesantren-pesantren di tanah Jawa dan Madura.

Integrasi ilmu agama dan ilmu umum ini, jika ditinjau dengan menggunakan konsep Fazlur Rahman merupakan sebuah inisiatif besar bagi terjadinya sebuah pembaruan dalam pendidikan Islam. Rahman menegaskan bahwa salah satu faktor yang mempengaruhi kemajuan pendidikan Islam di masa mendatang adalah integrasi keilmuan agama dan keilmuan umum. Rahman, sebagaimana dikutip Sutrisno (2006, 167) menegaskan upaya pembaruan pendidikan Islam melalui upaya mengikis dualisme sistem pendidikan tradisional (agama), dan pada sisi lain ada pendidikan modern (sekuler). Kedua sistem ini sama-sama tidak beresnya. Karena itu perlu ada upaya mengintegrasikan keduanya. Dengan demikian dapat dikatakan bahwa yang dilakukan oleh AWH dengan mengkomposisikan materi kurikulum 70\% ilmu umum dan 30\% ilmu agama di Madrasah Nizamiyah merupakan sebuah gagasan cemerlang agar sikap "mencurigai" sains dan pelajaran "orang kafir" bisa melunak. Mengajarkan geografi, matematika, maupun bahasa Asing merupakan wujud pengintegrasian ilmu umum dan ilmu agama yang telah dimulai melalui Madrasah Nizamiyah.

Implementasi gagasan AWH puluhan tahun silam ini senada dengan penilaian Azyumardi Azra (2006, 110) mengenai integrasi ilmu agama dan ilmu umum, maupun peniadaan dikotomis antara keduanya. Menurut Azra, walau Islam mengajarkan integralisme keilmuan. Ia menyebutnya tawhidic paradigmof sciences pada tingkat konseptual, tetapi harus diakui bahwa pada tingkat praksis tidak jarang terjadi disharmonisasi, dan dikotomi di antara keduanya. Bahkan dikotomi sering menjangkau epistemologis, yakni antara wahyu dengan akal, atau antara "ilmu-ilmu agama" dengan "ilmuilmu umum”. Sebab itu, guna mengatasi disharmonisasi dikotomi 
tersebut para pemikir dan ilmuwan Muslim menawarkan klasifikasi ilmu lengkap dengan hierarki mereka masing-masing.

Selain pengintegrasian ilmu umum dan ilmu agama, yang tampak dalam gagasan $\mathrm{AWH}$ adalah implementasi dari sebuah adagium yang berbunyi al-Muhafadhat 'ala al-Qadimal-SalihwaalAkhdzbial-Jadid al-Aslah yang secara bebas dimaknai sebagai upaya "menjaga sesuatu yang lama (klasik) yang positif, sambil mengadopsi sesuatu yang baru yang lebih aktual dan positif". Dalam hal ini, AWH tetap menggunakan perangkat keilmuan klasik sebagai sebuah hal yang tak terpisahkan di pesantren, dengan menerima pelajaranpelajaran baru yang dianggap baik untuk menunjang kemampuan para santri.

Selain pengajaran ilmu umum, di Madrasah Nizamiyah juga diajarkan keterampilan berbahasa asing. Pengajaran bahasa asing di madrasah ini, sesuai dengan keinginan $\mathrm{AWH}$ yang menginginkan agar bahasa menjadi sarana pembuka khazanah intelektual dan membuka pergaulan lebih luas. AWH berusaha mematahkan kesan bahwa lulusan pesantren adalah orang yang gagap dalam pergaulan luas, minder dalam keilmuan, dan kurang percaya diri. Kesan "tradisional" ini akan tetap dilekatkan kepada pesantren jika lulusannya tidak memiliki kemampuan kompetitif dibandingka dengan lulusan pendidikan lainnya (Feisal 1995, 190). Akan tetapi AWH tetap menggariskan pentingnya menggunakan bahasa Indonesia daripada bahasa asing saat berkomunikasi dengan sesama bangsa Indonesia. Ini adalah salah satu strategi memperjuangkan kemajuan bahasa Indonesia demi kemajuan bangsa. Pentingnya masalah bahasa ini ia tulis dalam "Kemajuan Bahasa, Berarti Kemajuan Bangsa (Atjeh 1957).

Selain itu, AWH juga mendukung sepenuhnya proses penerjemahan karya asing ke dalam bahasa Indonesia. Hal ini terlihat saat ia memberikan kata sambutan dalam buku terjemah hadis Shahih Bukhari pada tahun 1953 yang berjudul "Pentingnya Terjemahan Hadis pada Masa Pembangunan" (Atjeh 1957). Dalam kata sambutan tersebut, AWH mengingatkan bahwa ada kesalahpahaman atau salah kaprah di kalangan umat Islam bahwa yang berbau serba-Arab itu identik dengan Islam. Mereka belum bisa membedakan mana tradisi Arab yang memang milik bangsa Arab dengan ajaran Islam sehingga 
mereka mencampuradukkan keduanya menjadi satu, semuanya yang berbau Arab dianggap pasti Islam. Kesalahkaprahan inilah yang menurut $\mathrm{AWH}$ harus diluruskan dengan pendidikan, pengetahuan, dan penguasaan terhadap bahasa bangsa lain.

Inilah di antara pemikiran AWH tentang bahasa yang jauh hari sebelumnya ia terapkan di Madrasah Nizamiyah dengan memasukkan pengajaran bahasa asing. Selain itu, akibat dari terobosan melalui Madrasah Nizamiyah, maka jumlah santri juga semakin membludak. Ia dianggap sebagai pilot project pengembangan pesantren di masa depan (Zaini 2011a). Selain itu, AWH berusaha membawa terobosan di bidang pendidikan pesantren ini saat ia menjabat sebagai Ketua Departemen Pendidikan NU (LP Maarif). Ia membentuk panitia kecil yang mendiskusikan kemajuan lembaga pendidikan yang berada di bawah naungan NU. Salah satu keputusan yang dihasilkan adalah mendirikan madrasah NU sebagaimana di bawah ini madrasah umum, termasuk dalam kategori ini adalah madrasah Awwaliyah (dua tahun masa belajar), madrasah Ibtidaiyyah (tiga tahun masa belajar), madrasah Thanawiyah (tiga tahun masa belajar), madrasah Mu'allimin Wusta, madrasah Mu'allimin 'Ulya. Madrasah Ikhtisasiyyah (sekolah dengan keahlian khusus), di antara yang termasuk kategori ini adalah madrasah Qudat (sekolah hukum), madrasah Tijarah (sekolah ekonomi), madrasah Nijarah (sekolah kehutananan), madrasah Zira'ah (sekolah pertanian).

Sayangnya hanya kategori pertama yang bisa dilaksanakan, sedangkan kategori kedua belum bisa dilaksanakan karena terbatasnya ahli yang dimiliki oleh kalangan pesantren maupun NU di bidang tersebut (Atjeh 1957). Hal ini sesungguhnya menjadi tantangan bagi pesantren era sekarang untuk mengambangkan apa yang telah digagas oleh AWH melalui berbagai varian lembaga pendidikan Islam di atas. Dengan demikian, pesantren memiliki kapasitas melahirkan kaderkader yang tak hanya mahir di bidang keagamaan saja, melainkan juga bisa mendayagunakan kemampuan terbaiknya untuk masyarakat.

Menurut Aziz Masyhuri (Masyhuri 2008), AWH menyadari bahwa tujuan pendidikan Islam, khususnya dilingkungan pesantren saat itu, lebih terfokus dan terkonsentrasi ke wilayah akhirat, nyaris terlepas dari urusan dunia. Karena tujuan yang demikian, maka warna pendidikan pesantren sangat didominasi oleh warna fiqh, tasawuf, 
dan ritual sakral. Orientasi pendidikan pesantren ke masa lampau dan terpaku ke dunia sana, sedangkan dunia kini dianggap sebagai dunia mainan. Sebagaimana dikatakan oleh Dhofier, AWH tidak setuju dengan anggapan seperti ini. Hal ini ia tunjukkan dalam pengelolaan pesantren Tebuireng yang mengharuskan adanya pelajaran-peajaran umum dengan fondasi keagamaan (Lukens-Bull 2004, 66).

Strategi pembaruan pendidikan yang dilakukan oleh AWH, bisa dikatakan berhasil, karena beberapa hal penting yang selama ini diabaikan kalangan modernis. Pertama, pembaruan yang dilakukan oleh AWH tidak urban bias, maksudnya mengakar dan menyentuh akar rumput, karena para santri dan siswa madrasah umumnya adalah dari kalangan grassroot. Kedua, meskipun membawa aroma modern, akan tetapi AWH tidak menyerang dan mengucilkan ulama tradisional, karena sebagian besar umat Islam Indonesia berada di bawah pengaruh para ulama. Dan ketiga, kapasitas pribadi AWH cukup mumpuni untuk melakukan proses pembaruan didukung dengan faktor kecerdasan, geneologis pesantren dan implikasi pergaulan dengan tokoh pergerakan Islam dari berbagai kelompok (Basori 2006, 139).

\section{Pendidikan Islam Progresif}

Belajar dari pemikiran reformasi sistem pendidikan pesantren AWH, ada kesan bahwa subjek pendidikan Islam-baca para praktisi lembaga pendidikan Islam-untuk terus menerus melakukan pembenahan. Dalam konteks ini, istilah "pembenahan" dapat diartikan sebagai improvisasi kreatif sesuai dengan laju perkembangan ilmu pengetahuan dan teknologi atau bahkan melampuinya. Hal ini berarti perlu ada pemikiran-pemikiran progresif dalam konstruksi pendidikan Islam yang mampu untuk menyesuaikan dan menyelaraskan dengan masyarakat serta perkembangan ilmu pengetahuan dan teknologi. Jika alasan ini menjadi kesepakatan yang perlu dilakukan, maka perlu ada rekonstruksi pendidikan Islam untuk mengukuhkan alasan tersebut dan diimplementasikan sebagai alternatif solutif bagi problematika zaman.

Sebagaimana pemikiran AWH ketika ia melakukan rekonstruksi tujuan pesantren, maka rekonstruksi pendidikan Islam perlu ada agar rentang aksiologis tidak berjarak dengan 
akses stakeholder -baca pengguna output pendidikan Islam.Akan tetapi, landasan ontologis sebagai dasar pijakan normatif tidak turut berubah seiring dengan perubahan tuntutan stakeholder; seperti landasan tauhid dan berasaskan pada nilai al-Qur'an dan asSunnah-baca landasan teologis- tetap tidak akan berubah. Namun, berbeda dengan pemikiran-pemikiran filosofis yang cenderung berakar pada kemampuan rasionalitas bisa untuk diubah. Hal ini bisa menjadi jembatan dialogis antara landasan teologis dan realitas pendidikan Islam dalam kerangka filosofis. Hal ini yang sebenarnya telah dilakukan $\mathrm{AWH}$ di dalam membangun kerangka reformasi pendidikan pesantren yang muncul dari pembacaan realitas terutama untuk masa depan.

Salah satu bentuk pemikiran pendidikan Islam progresif AHW yang hingga saat ini masih terasa nilai kemanfaatannya adalah pendidikan Islam demokratis. Dalam kerangka ini AWH membuka ruang bagi peserta didik untuk terlibat langsung dalam meningkatkan kemampuan dirinya hingga ia mampu menjadi manusia yang kritis dan kreatif (Ismail 2016). Hal ini mengindikasikan, prinsip yang ada dalam konstruksi pemikiran pendidikan Islam AWH adalah upaya menyesuaikan ide kreatif paham keagamaan dengan laju perkembangan zaman yang muncul akibat bergulirnya ilmu pengetahuan dan tehnologi. Oleh sebab itulah, prinsip ini perlu diintegrasikan pada setiap insan pendidikan Islam seperti para akademisi atau peneliti.

Atas dasar tersebut, pendidikan Islam memang perlu terus menerus merentangkan dimensi epistemologis untuk mensejajarkan teori-teori pendidikan dengan perkembangan ilmu pengetahuan dan tehnologi. Artinya, konstruksi teori yang ada tidak hanya berorientasi pada aspek "kelangitan" yang memuat doktrin ketuhanan, kenabian, dan sorga neraka; akan tetapi, ia memuat orientasi yang "membumi" dengan muatan teori pengembangan ilmu pengetahuan keduniawian seperti sosiologi, politik, biologi, fisika, atau bahkan kedokteran. Hal ini tidak lepas dari alur epistemologis yang positivistik dengan indikator rasionalis, empiris, dan materialis seperti halnya Barat yang membangun peradabannya. Bedanya, pendidikan Islam tidak melepaskan diri dari kerangka dasar teologis monotoistik hingga nilai-nilai profetik menjadi ontos-aksiologik. 
Jelasnya, proses dialogis antara pendidikan Islam dengan realitas berjalan secara intensif dan terarah untuk masa sekarang dan yang akan datang. Artinya, proses ini terancang untuk menyelaraskan pendidikan Islam (seperti teori, tujuan atau konstruksi lainnya) dengan kecenderungan masyarakat (di dalamnya ada ilmu pengetahuan dan tehnologi). Proses ini pun tidak meninggalkan karakteristik epistemologis pendidikan Islam yang terpancang pada tiga hal, yaitu: dimensi bayani, burhani, dan irfani. Tiga dimensi-baca tehnik-epistemologis ini yang mengkerangkai realitas hingga bisa memunculkan pemikiran-pemikiran progresif; yang jika diskemakan akan tampak sebagaimana berikut:

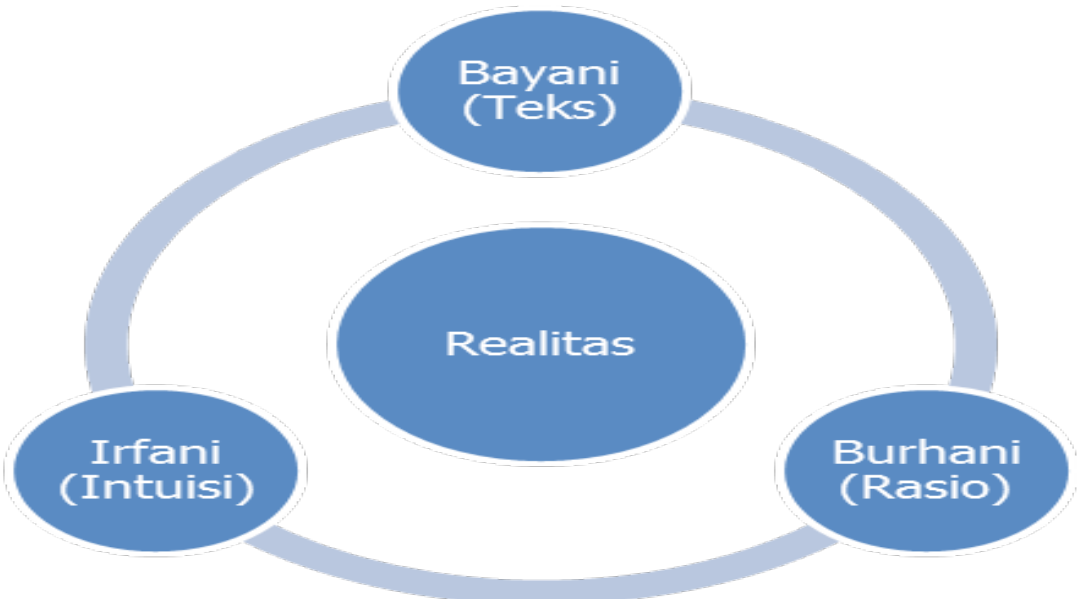

Kerangka pendidikan Islam yang demikian akan menuntun pada ranah pembentukan subjek -baca output dan outcome pendidikan yang sempurna. Subjek ini dalam kajian filsafat atau pemikiran pendidikan Islam diistilahkan dengan insan kamil; yaitu manusia universal yang merupakan representasi (teofani) dari nama-nama Tuhan. Dari konsep ini pun akan mendorong adanya keseimbangan pada perilaku subjek pendidikan sebagai sosok Abdullah dan juga khalifatullah. Abdullah mengorientasikan dirinya sebagai subjek yang berperilaku shaleh dengan landasan aqidah (monotoisme) yang kuat, sedangkan khalifatullah mengorientasikan diri sebagai pengembang dan pemakmur bumi melalui tata laku pengembangan ilmu pengetahuan dan tehnologi. Jika dikonseptualkan ke dalam suatu istilah lain, ulama' yang ilmuwan atau ilmuwan yang ulama' 
-jika ulama' diartikan sempit sebagai orang yang ahli dalam ilmu agama dan ibadah. Dengan demikian, pendidikan Islam merupakan suatu sistem pendidikan yang progressif untuk saat ini dan di masa yang akan datang.

\section{Kesimpulan}

Gagasan pembaruan dan modernisasi pesantren yang dirumuskan oleh AWH dapat dibilang sangat kontroversial pada saat itu, sebab banyak gagasan pembaruan masih dianggap asing. Walaupun demikian, gagasan AWH disambut baik oleh ayahnya, bahkan pada babakan dekade berikutnya model pembaruan ini mengilhami pesantren-pesantren lainnya untuk menerapkan gagasan pembaruan tersebut. Pada saat ini, gagasan tersebut diterapkan dengan berbagai corak inovasi pendidikan, yaitu: Mulai akrab dengan metodologi modern; Semakin berorientasi pada pendidikan yang fungsional, artinya terbuka atas perkembangan di luar dirinya; Diversifikasi program dan kegiatan makin terbuka dan ketergantungannya dengan kiai tidak absolut, dan sekaligus dapat membekali santri dengan berbagai pengetahuan di luar pelajaran agama maupun keterampilan yang diperlukan dunia kerja; dan Dapat berfungsi sebagai pusat pengembangan masyarakat. Hal ini mengasumsikan bahwa pada dasarnya pesantren kini sudah dan sedang mengalami transformasi kultur, sistem, dan nilai. 


\section{DAFTAR PUSTAKA}

Abdullah, Taufiq. 1996. Ensiklopedi Islam. 1 ed. Jakarta: Ichtiar Baru van Hoeve.

Arifin, Achmad Zainal. 2013. "Charisma and Rationalistion in a Modernising Pesantren: Changing Values in Traditional Islamic Education in Java." University of Western Sydney.

As'ad, Mahrus. 2012. "Pembaharuan Pendidikan Islam KH. Hasyim Asy'ari.” Tsaqafah: Jurnal Peradaban Islam 8(1): 105-34.

Atjeh, Aboebakar. 1957. Sedjarah Hidup KH. A. Wahid Hasjim dan Karangan Tersiar. Jakarta: Panitia Buku Peringatan Alm. K.H. A. Wahid Hasjim.

Azra, Azyumardi. 2006. Paradigma Baru Pendidikan Nasional: Rekonstruksi dan Demokratisasi. Jakarta: Kompas.

Azra, Azyumardi, dan Saiful Umam. 1998. Menteri-Menteri Agama: Biografi Sosial Politik. Jakarta: INIS-Litbang Depag.

Barton, Greg. 1997. “Indonesia's Nurcholish Madjid and Abdurrahman Wahid as Intellectual 'Ulama': The Meeting of Islamic Traditionalism and Modernism in neo-Modernism Thought." Jurnal Studia Islamika 4(1): 29-81.

—__ 2002. Abdurrahman Wahid: Muslim Democrat, Indonesian President. Australia: UNSW Press.

Basori, Ruchman. 2006. The Founding Father Pesantren Modern Indonesia. Banten: Inceis.

Dhofier, Zamakhsyari. 1982. Tradisi Pesantren: Studi tentang Pandangan Hidup Kyai. Jakarta: LP3ES.

———. 1984. "KH. A. Wahid Hasyim: Rantai Penghubung Peradaban Pesantren dengan Peradaban Indonesia Modern.” Prisma 8(8).

Feisal, Jusuf Amir. 1995. Reorientasi Pendidikan Islam. Jakarta: Gema Insani.

Ismail, Moh. 2016. "Demokratisasi Pendidikan Islam dalam Pandangan KH. Abdul Wahid Hasyim.” Jurnal Pendidikan Islam 4(2): 315-36. 
Latifah, Zuhrotul, dan T. Ibrahim Alfian. 2005. "Pandangan Tentang Agama dan Politik KH. A. Wahid Hasyim (1941-1952)." Jurnal Humanika 18(4): 513-26.

Lukens-Bull, Ronald Alan. 2004. Jihad Ala Pesantren di Mata Antropolog Amerika. Yogyakarta: Gama Media.

Ma'shum, Saifullah. 1994. Menapak Jejak Mengenal Watak: Sekilas Biografi 26 Tokoh Nahdlatul Ulama. Jakarta: Yayasan Saifuddin Zuhri.

Maragustam, M. 2016. "The Reformation of Pesantren Education System: The Study on Abdul Wahid Hasyim Thoughts the Perspective of Islamic Education Philosophy." Jurnal Pendidikan Islam 5(2): 325-46.

Masyhuri, KH. A. Aziz. 2008. 99 Kiai Kharismatik Nusantara,. Yogyakarta: Kutub.

NS., Sutarno. 2003. Perpustakaan dan Masyarakat. Jakarta: Yayasan Obor Indonesia.

Puspitasari, Nindia. 2017. "Pendidikan Karakter Perspektif Islam: Studi Pemikiran KH. Abdul Wahid Hasyim.” at-Tajdid 1(1): 105-23.

Santoso, Moh. Hadi, dan Sumarno. 2015. "Pembaharuan Sistem Pendidikan Pesantren Menurut KH. Abdul Wahid Hasyim.” Avantara: e-Journal Pendidikan Sejarah 3(3): 335-343.

Sanusi, Buntaran, Ronny Kaloke, dan Kusnandar. 1985. KHA. Wahid Hasyim Mengapa Memilih NU? Jakarta: PT. Inti Sarana Aksara.

Solikhin, Mat. 2016. "Gerakan Pemikiran dan Peran Tiga Ulama NU dalam Menegakkan Ahl Sunnah Wa 'l-Jama'ah al-Nahdiyyah di Jawa Tahun 1926-1971: Kajian terhadap Pemikiran KH. Hasyim Asy'ari, KHR. Asnawi, KH. Wahhab Hasbullah.” Jurnal Theologia 27(2): 331-64.

Suprapto, Bibit. 2009. Ensiklopedi Ulama Nusantara Riwayat Hidup, Karya dan Sejarah Perjuangan 157 Ulama Nusantara. Jakarta: Gelegar Media Indonesia.

Sutjiatiningsih, Sri. 1984. KHA. Wahid Hasyim: Riwayat Hidup dan Perjuangannya. Jakarta: Departemen Pendidikan dan Kebudayaan, Direktorat Jenderal Kebudayaan, Direktorat 
Sejarah dan Nilai Tradisional, Proyek Inventarisasi dan Dokumentasi Sejarah Nasional.

Sutrisno. 2006. Fazlur Rahman Kajian Terhadap Metode, Epistemologi dan Sistem Pendidikan. Yogyakarta: Pustaka Pelajar.

Syarif, Zainuddin, dan Abdul Gaffar. 2012. "Pendidikan Multikulturalisme Tauhidiq dalam Pemikiran KH. Abdul Wahid Hasyim." Jurnal Pendidikan Agama Islam 9(1): 23- 46.

Zaini, Achmad. 1998. "Kyai Haji Abdul Wahid Hasyim: His Contribution To Muslim Educational Reform and To Indonesian Nationalism During The Twentieth Century." McGill University.

——_. 2011a. KH. A. Wahid Hasyim: Pembaru Pendidikan Islam dan Pejuang Kemerdekaan. Jombang: Pustaka Tebuireng.

—__. 2011b. "KH. A. Wahid Hasyim: Pembaru Pendidikan Islam di Indonesia." Majalah Tempo. 